\title{
Luc Anckaert
}

\section{Goodness without Witnesses: Vasily Grossman and Emmanuel Levinas}

Life and Fate, the impressive novel on the battle of Stalingrad by the JewishRussian author Vasily Grossman, was first published in 1980, by L'Âge d'homme in Lausanne (Garrard \& Garrard 2012). Grossman had earlier submitted it in 1960, in a rather naive way, for publication in the post-Stalin period. Under the Khrushchev regime, there was little tolerance for criticizing Stalinism or comparing it to Nazism. However, instead of Grossman being arrested, as had happened to Boris Pasternak, it was the novel's manuscript, along with all copies and carbon papers of it, that were confiscated. The text - an emulation of Tolstoy's War and Peace (Emerson 2012) - subsequently lived an underground life. Levinas, after finishing his main works, read the Russian edition when he was 75 years old. In 1987, in the Poirié interview (Levinas 2001a, 80), he stated: "The great book which impressed me a lot, is the book by Vasily Grossman, Life and Fate, translated from the Russian, which I read in Russian.”

Although written in the same decade as Totality and Infinity (Levinas 1969), Life and Fate is not a source for Levinas. Nevertheless, it is interesting to confront the novel with some of Levinas's insights. In his post-1980 writings, Levinas refers several times to Grossman. Most of these texts are interviews. Sometimes, it concerns a short allusion, but there is an important exception: the Talmudic reading Beyond Memory (Levinas 1994a). For a discussion of the relation between Grossman and Levinas, I refer to two important books by Michael Morgan, Discovering Levinas (2007) and The Cambridge Introduction to Emmanuel Levinas (2011).

I concentrate on three topics. Two of them are represented by protagonists in Grossman's novel: the holy fool Ikonnikov and the childless mother Sofya Osipovna. The third is a reflection on the difference between both authors.

The ambiguous relation between individual goodness and structural justice is, in a divergent way, present in the works of both authors. I will investigate how Levinas integrates and critiques the socio-political intuitions of Grossman: the refusal of collaboration; the critique of ideologies and totalitarianism; the necessary injustice of just institutions; the violence of great ideas; the small goodness without witnesses; the goodness as radix of social life. I illustrate this in quoting Grossman and in indicating how Levinas 'uses' or reinterprets the 
literary texts of Grossman in his philosophical reflections. The thesis is that Levinas not only reads Grossman as an illustration or confirmation of his ideas, but that he develops an intellectual gesture by which Grossman's intuitions are changed in their radicalness and thereby integrated into the already elaborated ethical thinking after 1980. For example, the small goodness - in Grosmann, a critique of ideology - is reinterpreted as a source and a correction of the necessary institutions.

At a more fundamental level, Grossman and Levinas speak of the mystery of the human soul. This topic allows for delving into the deeper philosophical foundations of both authors. I am convinced there exists an unconscious congeniality between them - fostered by their experiences of violence and of goodness. This congeniality existed before Levinas read Grossman, as becomes evident in comparing some of Grossmans main intuitions with a Talmudic reading.

But there is also an unbridgeable gap: the individual protest against the violence of society - in a world that is no place and in the era of the wolfhound finds in Grossman its immanent sources in the indestructible power of human life; in Levinas, human life is opened by the alterity of certain old and sacred words.

\section{Goodness and Justice}

When Levinas refers to Grossman, it is almost always to the person of Ikonnikov, who is the incarnation of the small goodness. In chapter 67 of the novel's first part, we read a discussion, in the concentration camp, between some Mensheviks and the old Bolshevist Michael Mostovskoy. Mostovskoy is confronted with the thesis that “it's precisely Stalin's monstrous inhumanity that makes him Lenin's successor. As you love to repeat - Stalin is the Lenin of today" (LF, 285). The legitimacy of the violent terror as way of realization of the Marxist-Leninist ideal is at stake. During this ideological discussion IkonnikovMorzj comes to the fore, "a holy fool, that seeker after God" (LF, 304), a character type of which there are many in the work of Tolstoy. Ikonnikov's life represents the small goodness in a radical way. He gives Mostovskoy "some dirty sheets of paper covered in writing" (LF, 287) and asks him to read them. For the confrontation with Levinas, two intertwined topics are important: the radical refusal of the violence of the great ideologies and the plea for a humble goodness. 


\section{The Modest Refusal to Complicity}

Ikonnikov expects his own death. He knows that the wells he was forced to dig are intended for gas chambers. By doing so, he is preparing the terror. He resolutely refuses to cooperate with this death machinery, although this refusal means his own death. In the subsequent encounter with the priest Gardi, reminiscent of and an inversion of the passage "The Grand Inquisitor" in Dostoevsky's The Brothers Karamazov, he goes in against the statement that everyone participates and that God will forgive.

Ikonnikov reached up and grasped the bare foot of the priest sitting on the second tier of boards. "Que dois-je faire, mio padre? Nous travaillons dans una Vernichtungslager." Ikonnikov looked round at the three men with his coal-black eyes. "Tout le monde travaille là-bas. Et moi je travaille là-bas. Nous sommes des esclaves," he said slowly. "Dieu nous pardonnera." "C’est son métier," added Mostovskoy. "Mais ce n'est pas votre métier," said Gardi reproachfully.

"Yes, that's what you said, Mikhail Sidorovich," said Ikonnikov, speaking so quickly he almost tripped up over his own words, "but I'm not asking for absolution. It's wrong to make out that only the people in power are guilty, that you yourself are only an innocent slave. I'm helping to build an extermination camp; I'm responsible before the people who are to be gassed. But I'm free. I can say 'No!' What power can stop me if I have the strength not to be afraid of extinction? I will say 'No!' Je dirai non, mio padre, je dirai non!”

Gardi placed his hands on Ikonnikov's grey head. "Donnez-moi votre main," he said. "Now the shepherd's going to admonish the lost sheep for his pride," said Chernetsov. Mostovskoy nodded. But, rather than admonishing Ikonnikov, Gardi lifted his dirty hand to his lips and kissed it.

(LF, 288-289)

Ikonnikov refuses his responsibility to slide under the guise of a deadly command structure and comes on for his own freedom. This freedom is the source of the small goodness. It becomes manifest in the protest against the inevitable injustice. A few chapters later, the bed of Ikonnikov, who turns out to have been executed, is empty: "The holy fool? The man you used to call the blancmange? He was executed. He refused to work on the construction of an extermination camp. Keyze was ordered to shoot him” (LF, 515).

\section{The Violence of the Great Ideas}

The famous text fragments on the dirty sheets of paper held by Ikonnikov-Morzj are the subject of a discussion between the Communist prisoner Mostovskoy and the SS officer in command, Liss. In a well-written way, Grossman confronts the 
small goodness with the two great totalitarian visions of "the good," namely, Communism and Nazism. Do not the fascist Empire and the Socialist state exhibit a deep similarity? And are not both parties convinced of their own idiosyncratic truth? Each one acts always from a particular vision of the great good. "Even Herod did not shed blood in the name of evil; he shed blood in the name of his particular good" (LF, 389). The jarring insight that the idea of the good "sinks into the mire of life" (LF, 390) shows Grossman's unbelief "in the sermons of religious teachers and prophets, in the teachings of sociologists and popular leaders, in the ethical systems of philosophers" (LF, 391).

The problem of the good that leads to totalitarianism can be interpreted starting from Hannah Arendt. Although Arendt analyzes Nazism and Stalinism in her magisterial work The Origins of Totalitarianism (1951), we will start with The Human Condition (1969). Arendt differentiates three important aspects of human existence, each of which are connected with the human condition. Man is a product of nature; he is situated in a spatio-temporal environment in which he can build a world; and he lives together with others. Active life is a threefold answer to this condition. By labor, man keeps the human metabolism alive; by work he produces culture; and by acting he realizes a political society.

Work has a specific structure. In ancient Athens the craftsman and the artist were respected as those who create sustainable and unique products. It is a form of technique in which one realizes a pre-existent idea in the materiality. To this end, one needs certain means and resources. The means are extrinsically effective for the purpose. It is said that the neo-Platonic Michelangelo understood art production in the same way. The artist sees the ideal, projects it in the marble, and then strips away the unnecessary pieces. The realization of an artifact has to do with the imitation of an idea. The artist is inspired by a tupos. The concrete object is an imitation of a pre-existing example, a model, an idea. One can call this an onto-typological structure: a certain ideal or tupos is pressed upon the concrete things.

Acting has a different structure. As an interaction between people, acting does not intend to reach an extrinsic goal. The goal of action falls together with itself. For the Greeks, political action is the main example. Politics happens between free citizens and exists in the discussion between various interests. In politics, one not only realizes goals with all possible means, but also, especially in a democracy, one tries to achieve, by conversation, the common good. As such, political action is the opposite of the onto-typology of the technician.

However, Plato saw politics as the realization of pre-existing ideas. According to him, the fundamental structure of the work fits in another field of action of man, namely, politics. It was Plato, in The Republic, who first 
explained politics as a form of poièsis (that is, an act like a craftsman). He binds politics to a pre-existing idea, a paradigm, whose imitation or mimèsis ensures development of the good republic. The philosophers are inevitably the best rulers, because they are best-suited to a true understanding of the idea. Plato opposes the democracy because it is subject to discussion, to the undecidable plurality of opinions and the doxai.

When the ideas of the philosophers in the line of Plato predetermine how politics should appear, a radical distortion of the politics arises. Politics becomes the technical realization of a particular ideal. This happened in Communist Russia, where the idea and the aim of a non-alienated society determined all means (Popper 2003). Grossman writes:

\begin{abstract}
I have seen the unshakeable strength of the idea of social good that was born in my own country. I saw this struggle during the period of general collectivization and again in 1937. I saw people being annihilated in the name of an idea of good as fine and humane as the ideal of Christianity. I saw whole villages dying of hunger; I saw peasant children dying in the snows of Siberia; I saw trains bound for Siberia with hundreds and thousands of men and women from Moscow, Leningrad and every city in Russia men and women who had been declared enemies of a great and bright idea of social good. This idea was something fine and noble - yet it killed some without mercy, crippled the lives of others, and separated wives from husbands and children from fathers.
\end{abstract}

(LF, 390-391)

When acting is understood theoretically, the paradoxical result is that the ideal becomes murderous. Film lovers can think of the impressive scene from Doctor Zhivago in which a thunderous train, decorated with red flags, steams straight to the target. The dominance of the alleged ideal destroys everything on the road.

\title{
The Small Goodness
}

Opposite the weft of evil that lets explode history from the inside and destroys the human mysteries, there is the hidden force of the small goodness. The small goodness is placed in front of both systems, represented in Liss and Mostovskoy. Grossman makes a clear distinction between the good (dobro) and the goodness (dobrota). He believes only in the goodness that is focused on concrete men. The small goodness is the treatment of the other, regardless of any system and concept of the good. It is most strongly expressed by Ikonnikov: the dingy leaves he gives to Mostovskoy, accursed by his own regime, forms a tract on the small goodness. Ikonnikov offers them as "an inheritance without testament." Opposite the destructive power of the historical 
ideologies, based on the ideal of the great good, Ikonnikov describes the small "goodness without witnesses":

Yes, as well as this terrible Good with a capital "G," there is everyday human kindness. The kindness of an old woman carrying a piece of bread to a prisoner, the kindness of a soldier allowing a wounded enemy to drink from his water-flask, the kindness of youth towards age, the kindness of a peasant hiding an old Jew in his loft. The kindness of a prison guard who risks his own liberty to pass on letters written by a prisoner not to his ideological comrades, but to his wife and mother.

The private kindness of one individual towards another; a petty, thoughtless kindness; an unwitnessed kindness. Something we could call senseless kindness. A kindness outside any system of social or religious good.

But if we think about it, we realize that this private, senseless, incidental kindness is in fact eternal. It is extended to everything living, even to a mouse, even to a bent branch that a man straightens as he walks by.

Even at the most terrible times, through all the mad acts carried out in the name of Universal Good and the glory of States, times when people were tossed about like branches in the wind, filling ditches and gullies like stones in an avalanche - even then this senseless, pathetic kindness remained scattered throughout life like atoms of radium.

(LF, 391-392)

Levinas also stresses this goodness as opposed to the idea of the good:

The good rises, merely by the fact itself that, in the encounter, the other counts above all else. The Relationship where the I encounters the You is the original place and circumstance of the ethical coming [avènement]. The ethical fact owes nothing to values; it is values that owe everything to the ethical fact. The concreteness of the Good is the worth [le valoir] of the other man.

(Levinas 1998, 225)

\section{Levinas's Reading of Grossman}

The confrontation with Levinas can be elaborated on different levels. I will not discuss Levinas's interpretation of the relation between Nazism and Stalinism, although it is quite akin with Grossman. More relevant is Levinas's assessment of the small goodness and its relation to structural justice. It is clear that Grossman does not believe in any form of organized goodness. All institutions are based on sometimes good and brilliant ideas of justice, but in reality they are dehumanizing and monstrous. Levinas is impressed by the concept of the small goodness and he sees within it a challenge for his own thinking. Levinas, however, has a different view on structural justice. 
In Levinas's view, man is an interiority who, in meeting the other, is called to an endless responsibility. Although the call for responsibility is radical, it is limited by the presence of the many others. The ethical responsibility is not only the exclusive encounter between two people. There is also the third, the quantitative other, he who is not present in my life-circle; yet he is also the qualitative other, who escapes from any possibility to call me to responsibility. The thirds are these people who are not involved in the I-Thou relation. They can be absent in time and space. It is the aspect of the illeity. Although the thirds are unable to call for responsibility, they are also an object of responsibility. This kind of responsibility is not immediate, but must be mediated by institutions.

Within ethical dynamics, the thirds have an important place, in that their presence introduces the social dimension into ethics. Seen from the intimate I-Thou relation, the thirds mean a disruption in the personal ethical commitment. But the thirds show that the ethical commitment towards the singular other bears in itself the possibility of injustice. When one responds to the call of the other and thus becomes the unique person taking up the responsibility for the unique other, one does injustice to the many others. This is the tragedy of the small goodness. The ethical choice for the unique other necessarily implicates exclusion of the third.

Therefore, the responsibility must be organized in a structural way (Burggraeve 2015). The social and political field of action is, in a certain sense, the result of the appearance of many thirds, which cry for some degree of equality. Levinas's social ethics displays, in outline, the following structure. Man is self-directed (conatus essendi) and in meeting the other he is called to an endless responsibility. This infinite responsibility, however, is restricted by the appearance of the thirds, who also have their own rights. A potential conflict between the rights of the second other and the third others leads to the institution of a more or less just system. In The Other, Utopia and Justice, a text that mentions Grossman, Levinas states:

But the order of justice of individuals responsible for one another does not arise in order
to restore that reciprocity between the I and its other; it arises from the fact of the third
who, next to the one who is an other to me, is "another other" to me. The I, precisely as
responsible for the other and the third, cannot remain indifferent to their interactions,
and in the charity for the one cannot withdraw its love for the other. [. . . Behind the
unique singularities, one must perceive the individuals of a genus, one must compare
them [. . . . This is the hour of inevitable justice [. . . ]. The hour of justice, of the compari-
son between incomparables [. . . ].
(Levinas 2001f, 205-206) Thus, Levinas integrates the economic and political system into his thinking. The incomparable uniqueness of the many thirds can be valuated only by 
organizing a system of equality. In this way, responsibility receives a social structure.

The presence of the many others asks to organize responsibility. The individual responsibility is turned into a social solidarity. The paradox and tragedy of the organized solidarity consists in the fact that everyone is considered as equal. Any system overlooks the concrete face of the other. The system that seeks to ensure justice for the many becomes dehumanizing. This is the critique of Grossman, who wrote that even Herod initially acted from the idea of the good. But Grossman stresses that the little act of goodness (la petite bonté) from one person to his neighbor is lost and deformed as soon as it seeks organization, universality, and systemization.

For Levinas, this is not a reason to condemn the system. The totalizing aspects are absorbed as much as possible by a secondary instance of goodness. Since any system overlooks the concrete face of the other, the system needs to be continually corrected. Levinas is well aware of the totalizing compulsion inherent in the system. Responsibility for others becomes concrete in a world of power, money, and corruption. Therefore, the system that is necessary to organize the goodness must be put under permanent critique. In doing so, it can be corrected. This correction can happen in the small goodness. It is the refuge of the good in being.

This leads to a justice always to be perfected against its own harshness. Legislation always unfinished, always resumed, a legislation open to the better. It attests to an ethical excellence and its origin in goodness.

(Levinas 2001, 206-207)

Grossman and Levinas offer similar descriptions of the ethical commitment. For Grossman the small goodness is a critique against the fate of totalitarian systems. For Levinas, this goodness is the radix of the legislation that in its necessary calculation always disrupts the goodness. Levinas interprets the small goodness to be a correction of the impersonality of a system that both tries to realize justice but also disregards the invisible tears of people who, despite all their efforts, fall outside of this whole.

\section{The Small Goodness and the Mystery of the Soul}

The first part of this discussion was thematic. After reading Life and Fate, Levinas was struck by the concept of the small goodness and understood it as a challenge for his own ethical thinking. For Grossman, freedom remains 
possible in an inhuman world of violence. This freedom realizes itself as small goodness. For Levinas, ethical responsibility is the refutation of war (Levinas $1969,21)$. At first sight, one might think to oppose freedom in Grossman to responsibility in Levinas. Rather than explore this potential yet superfluous antithesis, I wish to look for an unconscious congeniality between the two authors, both of whom link the small goodness to the mystery of the soul.

In his description of the small goodness, Grossman labels it the immortal secret of human existence that manifests itself in the deepest darkness.

The powerlessness of kindness, of senseless kindness, is the secret of its immortality. It can never be conquered. The more stupid, the more senseless, the more helpless it may seem, the vaster it is. Evil is impotent before it. The prophets, religious teachers, reformers, social and political leaders are impotent before it. This dumb, blind love is man's meaning.

But the more I saw of the darkness of Fascism, the more clearly I realized that human qualities persist even on the edge of the grave, even at the door of the gas chamber.

(LF, 394)

Sofya Osipovna, a childless doctor, is on the threshold of the gas chamber, on the edge of the abyss. The goodness happens between people and is not chronicled in the annals of history. It originates in the secret of the soul and is located in the cryptic caving of "the anus mundi" (Kielar 2009):

For a moment this sense of her past blotted out everything present, blotted out the abyss. It was the very strangest of feelings, something you could never share with any other person - not even your wife, your mother, your brother, your son, your friend or your father. It was the secret of your soul. However passionately it might long to, your soul could never betray this secret. You carry away this sense of your life without having ever shared it with anyone: the miracle of a particular individual whose conscious and unconscious contain everything good and bad, everything funny, sweet, shameful, pitiful, timid, tender, uncertain, that has happened from childhood to old age - fused into the mysterious sense of an individual life.

$(\mathrm{LF}, 527)$

Sofya Osipovna recognizes the eternal secret in another woman, Deborah:

The machinist's wife was walking along beside her; in her arms the pathetic little baby, its head too large for its body, was looking around with a calm, thoughtful expression. It was this woman, Deborah, who one night in the goods-wagon had stolen a handful of sugar for her baby. The injured party had been too feeble to do anything, but old Lapidus had stood up for her [. . .]. No one had wanted to sit near him - he was always urinating on the floor. And now Deborah was walking along beside her, holding her baby in her arms. And the baby, who had cried day and night, was quite silent. The woman's sad dark eyes stopped one from noticing the hideousness of her dirty face and pale crumpled lips. “A Madonna!” thought Sofya Levinton.

(LF, 528-529) 
The topic of the secret of the soul expresses the common unconscious intuition that structures the economy of the texts of both authors. Levinas reflects on the mystery of the human soul in his Talmudic commentary And God Created Woman (Levinas 1990; Anckaert 2009). The Hebrew word vayyitzer (creates) contains an orthographic failure: the word is written with a double yod. Why? Levinas stumbles on this detail: it must have a meaning. His final proposal is that the double yod refers to a double face. This interpretation is taken not from Genesis, where it would mean the faces turned to each other and the erotic attraction of man and woman, but from Psalm 139:5, which explains the anomaly: "You hedge me before and behind; You lay Your hand upon me." Man has a double face. With one face, the back of the subject's head remains hidden as a shelter for dark thoughts. With two faces, everything is visible and there remain no mental reservations. God's gaze sees man in all directions, into life and death. There is no refuge or hidden place left. God's hand seizes and leads man everywhere. There is no escape to the left or to the right, up or down. From the contexts of the Psalm verse it seems to be impossible to escape from God or not to be present to his eye without sleep. This look, however, is no misfortune but rather an obsessive election. It is a complete visibility of man to the eye of the invisible. Later in the text this is called "the mystery of the human psyche" (Levinas 1990, 170). Man's secret is no hidden and impenetrable unconsciousness, but the complete visibility of the face to God's eye.

The (in)visibility can be understood according to two modalities (Derrida 1995). Something which is invisible can be made visible by a change of position or a revelation (e.g., the back of a cupboard or the contents of a box). The lifting of this invisibility by Abschattungen (Husserl) leads to the constitution of an ideal object. There is a further invisibility which cannot be lifted because the invisible is beyond visibility (e.g., a smell). In the Psalm text every darkness or secrecy becomes visible to God's eye and there is no escape left. There is a visibility of the first order. And yet this visibility is there only to the eye of the transcendence. To one's fellow man there is still invisibility. As with Gyges, the mystical relationship, where everything becomes visible, is invisible to the outside world. But the transparency to God's eye does not mean that man can see God. Although the subject is visible, God remains invisible.

The parabola of the double face has yet a deeper meaning. The infinity, which sees through the finite, refers to the neighbor whose face calls for a new responsibility. Under God's eye without sleep one is the bearer of another subject. The mysterious being seen by God is a responsibility for the other. The gift of the Torah consists in an ethical commitment. When the skin completely 
turns into a face, the being experiences a shelling. This synonym for decomposition refers to a hidden inner core which is exposed. The naked existence to God's eye - by which the whole skin becomes visible and there can be no secrecy left - is the place where responsibility for the neighbor is registered. The double face means the impossibility of pretending that one does not see the other's need.

This mystery is a responsibility. The infinity refers to the other whose face calls for a responsibility. Under God's eye, one is the bearer of another subject. Being born by infinity means the task to bear the other. The woman bears the child:

Sofya Levinton felt the boy's body subside in her hands. Once again she had fallen behind him. In mine-shafts where the air becomes poisoned, it is always the little creatures, the birds and mice, that die first. This boy, with his slight, bird-like body, had left before her. "I've become a mother," she thought. That was her last thought.

$(\mathrm{LF}, 538)$

\section{Goodness without Hope or Hope without Promise}

In the previous section, I alluded to a possible congeniality between Grossman and Levinas. There is an underground source of their thoughts: their mutual understanding of the mystery of the human soul. This mystery is the confrontation with the suffering and death of the other as source of the goodness without witnesses. But the difference is great: atheism and despair versus religion and hope. This becomes clear in Grossman's interpretation of the Madonna and Levinas's interpretation of the rahamim.

In 1955 Grossman wrote the splendid short text The Sistine Madonna (Grossman 2010). The painting in question, by Rafael, had been stolen by the Red Army from the Dresden Art Gallery and removed to Moscow. Before its return to Dresden, the painting was exhibited in May 1955 at the Pushkin Museum. Grossman was struck by the immortality of the painting: "I realized that I had, until this moment, been careless in my use of this awesome word "immortality"' (Grossman 2010, 181). The secret of the painting is that the body and the face of the young woman show her soul: "Everyone who looks at her can see her humanity. She is the image of the maternal soul” (Grossman 2010, 183). The Madonna is completely human, without any divine participation (Garrard 2012, 328). The child also has his own lucidity. The spectator can perceive the child's fate through his sad and serious expression, directed 
simultaneously ahead and within himself. Mother and child feel their own Golgotha; they can be seen in the hell of Treblinka:

This was how mothers and children looked, this was how they were in their souls when they saw, against the dark green of the pine trees, the white walls of the Treblinka gas chambers.

(Grossman 2010, 187)

How many times had I stared through darkness at the people getting out of the freight wagons, but their faces had never been clear to me. Sometimes their faces had seemed distorted by extreme horror, and everything had dissolved in a terrible scream. Sometimes despair and exhaustion, physical and spiritual, had obscured their faces with a look of blank, sullen indifference. Sometimes the carefree smile of insanity had veiled their faces as they left the transport and walked towards the gas chambers. And now at last I had seen these faces truly and clearly. Rafael had painted them four centuries earlier. This is how someone goes to meet their fate.

(Grossman 2010, 187-188)

It was she, treading lightly on her little bare feet, who had walked over the swaying earth of Treblinka.

(Grosmann 2010, 187)

The power of life, the power of what is human in man, is very great, and even the mightiest and most perfect violence cannot enslave this power; it can only kill it.

(Grossman 2010, 191)

Grossman reads the soul of the mother in a completely atheistic way. He interprets human life and freedom as the only seat of humanity. Only this humanity has eternal value and can resist inhumanity. The text concludes:

Seeing the Sistine Madonna go on her way, we preserve our faith that life and freedom are one, that there is nothing higher than what is human in man. This will live forever and triumph.

(Grossman 2010, 192)

Whereas Grossman believes in a goodness without hope, Levinas is driven by a hope without promise. Here we discover the decisive difference between the two authors: in Levinas's intuition that the secret of humanity is born by the alterity of transcendence. In Grossman, man dwells in a desperate world wherein he can keep his humanity by realizing small goodness. But the mother Osipova bears a death child. There is no hope for the future.

Levinas integrates his great reference to Grossman in the context of the Shoah. In his Talmudic reading Beyond memory he states "that war of Gog and Magog may have already begun in this century of Shoah" (Levinas 1994a, 88). Levinas explicitly links the small goodness with two Hebrew words. The first word of difference is the ahavat Israel (the love for Israel), the hope escaping from the abyss of despair (Levinas 1994a, 89). The ahavat Israel "may be the 
original tenderness for the other, the compassion and mercy" (Levinas 1994a, 89). This ahavat is contributed to Abraham, the father of many nations (Anckaert 2008). It is a promise without hope: "What a paradox Holy History is - in which the announcements to Abraham implies the certainty of the cruelty of the Pharaohs" (Levinas 1994a, 88).

The second word of difference is the rahamim, translated here as mercy. In its Hebrew form it is used in The Bible and the Greeks, another text in which Levinas refers to Grossman. It is "the goodness of one person toward another, the little kindness I have called mercy, the rahamim of the Bible" (Levinas 1994b, 135). It is "an invincible goodness" that "bears witness, in the mode of being our Europe, to a new awareness of a strange (or very old) mode of spirituality or a piety without promises, which would not render human responsibility - always my responsibility - a senseless notion. A spirituality whose future is unknown" (Levinas 1994b, 135). Rahamim is the mercy of a human being who bears another human being, like a woman bearing a living child in her womb (Rehem, in Hebrew). It is the utmost passivity that precedes goodness. This passivity is the hope without promises that prevents human responsibility from being a senseless notion. The goodness is the sign of a still unknown God. The unknown God is not Heidegger's (Heidegger 2000), but He is the God of a very old text - the Torah, which is older than the world. Humanity is made possible by a word that is created before the creation of the world.

\section{Conclusion}

The small goodness is the crux in comparing Levinas and Grossman. This tender form of humanity has a different place in the topicality of the two authors' respective socio-political texts. On a deeper level, one can discover an unconscious congeniality. The small goodness is the revelation of the mystery of the human soul. This soul is the feminine secret of Sofya Osipovna and of the created man. The ultimate difference that constitutes Levinas and Grossman's mutual congeniality is the unknown God of the sacred text. Levinas's thinking starts from the verses; the pages of Grossman contain none (Levinas 1994b, 135).

Are these truths present in a forgotten corner of some letters or syllables from Scripture, waiting to become God's word in the Jewish and the non-Jewish suffering of the twentieth century, in a time without promises and with a God who doesn't offer a shelter? 


\section{Bibliography}

\section{Texts of Levinas Referring to Grossman}

Levinas, Emmanuel. “Paix et proximité.” Les cahiers de la nuit surveillée 3. Lagrasse: Verdier, 1984. 339-346.

Levinas, Emmanuel. "Entretien (propos receuillis par L. Adert et J.-C. Aeschlimann).” Répôndre d'autrui. Ed. J.-C. Aeschlimann. Boudry-Neuschâtel: La Baconnière, 1989. 9-16.

Levinas, Emmanuel. De l'oblitération. Entretien avec Françoise Armengaud à propos de l'oeuvre de Sosno. Paris: La Différence, 1990.

Levinas, Emmanuel. "Beyond Memory." In the Time of the Nations. Trans. M. B. Smith. London: The Athlone Press, 1994a. 76-91.

Levinas, Emmanuel. "The Bible and the Greeks." In the Name of the Nations. Trans. M. B. Smith. London: The Athlone Press, 1994b. 133-135.

Levinas, Emmanuel. God, Death, and Time. Trans. B. Bergo. Stanford: Stanford University Press, (2000).

Levinas, Emmanuel. "Interview with François Poirié." Is it Righteous to Be?: Interviews with Emmanuel Levinas. Ed. J. Robbins. Stanford: Stanford University Press, 2001a. 23-83.

Levinas, Emmanuel. "Interview with Myriam Anissimov." Is it Righteous to Be?: Interviews with Emmanuel Levinas. Ed. J. Robbins. Stanford: Stanford University Press, 2001b. 84-92.

Levinas, Emmanuel. "The Vocation of the Other." Is it Righteous to Be?: Interviews with Emmanuel Levinas. Ed. J. Robbins. Stanford: Stanford University Press, 2001c. 105-113.

Levinas, Emmanuel. "Being-Toward-Death and 'Thou Shalt Not Kill.”' Is it Righteous to Be?: Interviews with Emmanuel Levinas. Ed. J. Robbins. Stanford: Stanford University Press, 2001d. 130-139.

Levinas, Emmanuel. "In the Name of the Other." Is it Righteous to Be?: Interviews with Emmanuel Levinas. Ed. J. Robbins. Stanford: Stanford University Press, 2001e. 188-199. Levinas, Emmanuel. "The Other, Utopia and Justice." Is it Righteous to Be?: Interviews with Emmanuel Levinas. Ed. J. Robbins. Stanford: Stanford University Press, 2001f. 200-210. Levinas, Emmanuel. "The Proximity of the Other." Is it Righteous to Be?: Interviews with Emmanuel Levinas. Ed. J. Robbins. Stanford: Stanford University Press, 2001g. 211-218.

\section{Other texts}

Anckaert, Luc. "The Secret of Abraham and its Repetition. A Narrative Reflection on the Relation between Faith and Ethics." Responsibility, God and Society. Theological Ethics in Dialogue. Festschrift Roger Burggraeve. Eds. J. De Tavernier, J. Selling, J. Verstraeten, and P. Schotsmans. Leuven: Peeters, 2008. 25-48.

Anckaert, Luc. "L'être entre les lettres. Creation and Passivity in 'And God Created Woman." Radical Passivity: Rethinking Ethical Agency in Levinas. Ed. B. Hofmeyr. Dordrecht: Springer Academic Publishers, 2009. 143-154.

Anckaert, Luc. "The Thunderbolt of Evil and Goodness without Witnesses: In Conversation with Vasili Grossman, Life and Fate." Religija ir Kultura 18-19 (2016): 22-37.

Arendt, Hannah. The Human Condition. Chicago: University of Chicago Press, 1969. 
Arendt, Hannah. The Origins of Totalitarianism. San Diego: Harcourt, 1994.

Burggraeve, Roger. "Ethics as Crisis: Levinas' Contribution to a Humane Society." Emmanuel Levinas: A Radical Thinker in the Time of Crisis. Ed. R. Serpytyte. Vilnius: Vilnius University Press - Vilniaus Universiteto Leydikla, 2015. 9-26.

Derrida, Jacques. The Gift of Death. Trans. D. Wills. Chicago: The University of Chicago Press, 1995.

Emerson, Caryl. "War and Peace. Life and Fate." Common Knowledge 18.2 (2012): 348-354.

Garrard, John, and Carol Garrard. The Life and Fate of Vasily Grossman. South Yorkshire: Pen \& Sword, 2012.

Grossman, Vasily. Life and Fate. Trans. Robert Chandler. London: Vintage Books, 2006. (LF)

Grossman, Vasily. "The Sistine Madonna." The Road: Short Fiction and Articles. Trans. Robert Chandler and Elizabeth Chandler with Olga Mukovnikova. London: MacLehose Press, 2010. 181-192.

Heidegger, Martin. "Spiegel-Gespräch mit Martin Heidegger [23. September 1966]." Gesamtausgabe, Band 16: Reden und andere Zeugnisse eines Lebensweg. Frankfurt am Main: Vittorio Klostermann, 2000. 652-683.

Kielar, Wieslaw. Anus Mundi. Fünf Jahre Auschwitz. Trans. Wera Kapkajew. Frankfurt am Main: Fischer, 2009.

Levinas, Emmanuel. Totality and Infinity. An Essay on Exteriority. Trans. Alphonso Lingis. The Hague: Martinus Nijhoff, 1969.

Levinas, Emmanuel. De Dieu qui vient à l'idée. Paris: Vrin, 1998.

Levinas, Emmanuel. “And God Created Woman.” Nine Talmudic Readings. Trans. Annette Aronowicz. Bloomington: Indiana University Press, 1990. 161-177.

Morgan, Michael L. Discovering Levinas. Cambridge: Cambridge University Press, 2007.

Morgan, Michael L. The Cambridge Introduction to Emmanuel Levinas. Cambridge: Cambridge University Press, 2011.

Popper, Karl. The Open Society and Its Enemies. London: Routledge, 2003. 
